\title{
LOKALITAS PADA TATANAN KAWASAN CANDI BARU SEMARANG
}

\author{
Locality in The Area of Candi Baru Semarang
}

\author{
Albertus Sidharta Muljadinata'; Antonius Ardianto ${ }^{2}$ \\ 1,2Program Studi Arsitektur, Fakultas Arsitektur dan Desain, Universitas Katolik Soegijapranata \\ Jl. Pawiyatan Luhur Sel. IV No.1, Bendan Duwur, Kec. Gajahmungkur, Kota Semarang, Jawa Tengah \\ *corresponding author: sidharta@unika.ac.id
}

\begin{abstract}
Abstrak
Dalam era globalisasi sangat menarik untuk mencermati pengembangan dan perkembangan berbagai kota di Indonesia. Yang sering terlihat, pada beberapa kota dialami perkembangan yang kacau pada bagian kotanya. Di sisi lain, terdapat bagian kota yang tetap dan tak berubah. Dalam kasus Kota Semarang, terdapat bagian kota yang relatif tidak berubah. Bagian kota yang tidak berubah ini merupakan hasil perencanaan kota oleh Karsten, seorang arsitek Belanda dan dia juga sebagai penasehat kota pada era penjajahan Belanda. Kota Semarang merupakan kota yang direncanakan oleh Karsten secara utuh. Latar belakang akademik, ideologi serta situasi sosial politik yang mempengaruhinya, mempunyai andil besar pada Karsten dalam merancang kota dan arsitekturnya. Dari fakta sejarah diketahui, perencanaan kota dan arsitektur yang mampu bertahan adalah yang memiliki konsep perencanaan yang menerapkan lokalitas. Kasus Penelitian ini ada pada sebagian segmen kawasan Kota Semarang. Dari pemahaman berbagai teori-teori tentang kota, arsitektur, dan lokalitas, akan didapat dominasi dan peran aspek lokal dalam karyanya. Penelitian ini bertujuan untuk mengungkap aspek lokal pada konsep pemikiran Karsten pada kasus studi. Manfaat penelitian ini adalah sebagai referensi di dalam mengembangkan ilmu arsitektur. Penelitian ini juga akan memberi wawasan baru kepada para masyarakat akademisi tentang pentingnya aspek lokal pada perencanaan kota dan arsitektur, serta akan memberi kejelasan, bahwa suatu kota akan tetap bertahan bila memiliki arsitektur kota memiliki relasi dengan lokalitas setempat. Kontribusi penelitian kepada masyarakat adalah sebagai masukan untuk menciptakan lingkungan yang baru pada artifak kotanya, melalui pendekatan konservasi kawasan kota yang baik.
\end{abstract}

Kata kunci: Konsep lokal, elemen primer kota, Karsten, karya Karsten.

\section{Abstract}

In the era of globalization, it is very interesting to observe the development and development of various cities in Indonesia. What is often seen is that some cities experience chaotic developments in their parts of the city. On the other hand, there is a fixed and unchanging part of the city. In the case of Semarang City, there are parts of the city that are relatively unchanged. This part of the city that has not changed is the result of urban planning by Karsten, a Dutch architect and he was also a city advisor during the Dutch colonial era. The city of Semarang is a city planned by Karsten in its entirety. His academic background, ideology as well as the socio-political situation that influenced him, had a big hand in Karsten in designing the city and its architecture. From historical facts, it is known that urban planning and architecture that are able to survive are those that have a planning concept that applies locality. The case of this research is in some segments of the Semarang City area. From the understanding of various theories about the city, architecture, and locality, it will be obtained the dominance and role of local aspects in his work. This study aims to reveal local aspects of Karsten's concept of thought in the case study. The benefit of this research is as a reference in developing the science of architecture. This research will also provide new insights to the academic community about the importance of local aspects in urban planning and architecture, and will provide clarity, that a city will survive if the city's architecture has a relationship with 
the local locality. The contribution of research to the community is as an input to create a new environment for the city's artifacts, through a good urban area conservation approach.

Keywords: local concept, primary elements of the city, Karsten, Karsten's work.

\section{Pendahuluan}

Karsten memiliki hampir lima puluh karya arsitektur dan perencanaan kota di Indonesia (Akihary, 1988: 99) [1]. Selanjutnya, dari data Huib Akihary ini, diketahui bahwa hampir setengah dari jumlah ini berada di Kota Semarang. Jadi dapat disimpulkan, bahwa bila dibandingkan kota-kota lain di Hindia Belanda, dia paling banyak meninggalkan warisan karya perencanaan kota dan arsitektur di Kota Semarang. Dengan demikian, Kota Semarang layak diteliti karena penelitian yang terkait dengan pembentukan Kota Semarang sebagai Kota Modern yang terkait dengan aspek lokal, belum pernah dilakukan.

Saat ini telah ada beberapa tulisan/karya ilmiah mengenai Karsten namum tulisan/penelitian ini sebagian besar tentang karya arsitektur dan perannya sebagai penasehat kota saat penjajahan Belanda.

Pada masa penjajahan kolonial Belanda di Indonesia, permukiman Kota Semarang direncanakan berdasarkan ras atau etnik, dan Kota Semarang terbagi menjadi kawasan kota kolonial, kawasan pecinan dan kawasan kauman. Semuanya ini dibangun tanpa ada perencanaan yang menyeluruh, proses ini merupakan tahapan awal terbentuknya Kota Semarang. Pada tahun 1910 gemeente Kota Semarang merencanakan perluasan kota, dan menugaskan Karsten untuk merencanakan perluasan Kota Semarang.

Untuk mengetahui posisi penelitian ini, dilakukan penelaahan terhadap studi-studi terdahulu yang ditemukan, yang berkaitan dengan konsep pemikiran Karsten dalam merencanakan kota. Karya ilimiah penelitian tentang Karsten sangat jarang ditemui, maka haruslah dicari dan dipilih artikel jurnal ilmiah, disertasi, dan tulisan tentang biografi Karsten. Hal ini dimaksudkan untuk memahami semua pemikiran yang memengaruhi Karsten dalam berkarya.

Berangkat dari penelitian disertasi, dan artikel jurnal internasional yang telah membahas tentang Karsten, tidak ada substansi penelitian yang secara khusus mendalami pengaruh lokalitas pada perencanaan Kota Semarang oleh Karsten Berdasarkan kenyataan ini, maka penelitian tentang konsep lokal pada pemikiran Karsten layak dilakukan.

Berdasarkan fenomena adanya aspek lokal yang diduga terkait dengan karya Karsten, maka penelitian ini berfokus pada aspek lokal pada karya Karsten. Dengan demikian isu spesifik dalam penelitian ini adalah diterapkannya lokalitas pada perencanaan Kota Semarang oleh Karsten. Isu ini belum pernah dibahas dalam penelitian Arsitektur. Dengan demikian, novelty penelitian adalah memahami lokalitas yang memengaruhi pemikiran Karsten dalam perencanaan kawasan kasus studi.

Berdasarkan fakta ini, maka rumusan masalah penelitian ini adalah menginterpretasi konsep pemikiran Karsten secara umum berdasar literatur dan fakta lapangan yang ada. Penelitian ini bertujuan untuk mengungkap aspek lokal pada konsep pemikiran Karsten pada kasus studi. Manfaat penelitian ini adalah sebagai referensi di dalam mengembangkan ilmu arsitektur. Penelitian ini juga akan memberi wawasan baru kepada para masyarakat akademisi tentang pentingnya aspek lokal pada perencanaan kota dan arsitektur, serta akan memberi kejelasan, bahwa suatu kota akan tetap bertahan bila memiliki arsitektur kota memiliki relasi dengan lokalitas setempat.

Ir. Herman Thomas Karsten adalah seorang arsitek Belanda dan perencana kota. Karsten meninggalkan Eropa pada tahun 1914. la berkomitmen pada diri 
sendiri untuk berkarier di Indonesia, dia hidup dan bekerja di Indonesia selama 30 tahun (Coté, 2017: 11) [2]. Pada saat Karsten tiba di Indonesia, sudah terdapat beberapa usaha penataan kota dan perumahan. Terutama usaha yang dilakukan pemerintah daerah setelah dikeluarkannya kebijaksanaan 'Desentralisasi' tahun 1903, saat itu mereka mulai tertarik pada masalah perkotaan, dan hal yang sama terjadi juga di Belanda setelah muncul UndangUndang Perumahan ('Housing Act") tahun 1901, yang secara bertahap mulai dilaksanakan. Pada tahun 1920 an - 1930 an, Karsten membangun reputasi sebagai penasehat perencana kota; namun ia juga aktif sebagi seorang arsitek. Dalam hal ini ia bekerja bertahun-tahun bagi dua belas dari sembilan belas penguasa lokal di Jawa, bagi tiga penguasa lokal di Sumatera dan bagi sebuah penguasa lokal di Kalimantan (Muljadinata, 1994: 1-2) [3].

Beberapa kota di Indonesia yang termasuk dalam usulan perencanaan Karsten antara lain: Jakarta, Bandung, Semarang, Surabaya, Malang, Magelang dan Sukabumi. Selanjutnya karya Karsten menyebar ke kota Cirebon, Jatinegara, Yogyakarta, Surakarta, Purwokerto, Sumatera (Palembang, Padang dan Medan), dan Banjarmasin di Kalimantan (Nas, 1986: 74-75) [4]. Berdasarkan fakta ini, dapatlah disimpulkan bahwa Karsten merupakan tokoh yang sangat penting bagi pembentukan kota-kota di Indonesia. Karsten adalah orang yang pertama menerapkan konsep town planning, yang sebelumnya belum pernah diterapkan di Indonesia. Dalam merencanakan perluasan Kota Semarang, Karsten merencanakan Semarang sebagai kota modern yang meliputi lima wilayah antara tahun 1916 sampai dengan 1924 [5], yang tidak berubah dalam perkembangannya sampai dengan masa kini. Selain merencanakan perluasan Kota Semarang, Karsten juga merancang banyak bangunan di Kota Semarang. Artefak karya Karsten meliputi rancangan arsitektur dan perluasan kota. Jadi dapatlah dikatakan bahwa Karsten merupakan tokoh penting yang berperan dalam perancangan arsitektur dan kota di Kota Semarang, juga di beberapa kota di Indonesia.
Karsten menikah dengan ibu Soembinah, seorang wanita asli Jawa, dan hal ini membawanya kepada pengalaman dan pemahaman akan budaya Jawa (Coté, 2017: 24) [2]. Hal ini jelas sangat mempengaruhi cara berpikir Karsten dalam berkarya sebagai arsitek dan penasehat kota. Pemikiran masyarakat Jawa, dengan budaya, tradisi dan adat istiadatnya, menjadi kekayaan lokalitas yang mempengaruhi Karsten. Jawa memiliki berbagai keindahan budaya dan seni yang terintegrasi dalam kehidupan masyarakatnya [6].

Pengaruh budaya setempat memengaruhi Karsten dalam berkarya sebagai arsitek. Pada tahun 1917-1920 Karsten memiliki pengalaman praktis mengenai bangunan rumah joglo ketika ia dipercaya menjadi penanggung jawab untuk perluasan modifikasi keraton Mangkunegara VII di Surakarta. Karsten memperlihatkan perhatian yang besar pada penduduk asli dan kebudayaannya, terutama pada arsitektur dan tata ruang kota. Sebagai arsitek, Karsten memberi perhatian penuh pada penggalian potensi dan sumber-sumber bentuk bangunan lokal tradisional (Muljadinata, Ardianto, 2004: 2) [7]. Pada beberapa karyanya, terlihat Karsten juga mau mempelajari kearifan lokal sehingga dapat menghasilkan karya arsitektur yang inovatif. Budaya pada lokasi bangunan dan fungsi/peruntukan bangunan menjadi unsur penting di dalam merancang karya arsitektur (Muljadinata, 2018:12) [8].

\section{Metode}

\section{Kasus Studi}

Pemilihan kasus studi dilakukan secara empirik terhadap karya Karsten di Semarang yaitu memilih karya arsitektur dan perluasan kota yang mencerminkan pengaruh aspek lokal dalam rancangannya. Dengan demikian dipilih karya Karsten yang sangat menampilkan adanya pengaruh aspek lokal.

Kota Semarang sebagai objek studi, adalah ibukota Jawa Tengah, pada pulau Jawa di Indonesia (gambar 1, 2, 3). Kasus 
studi berada di Kota Semarang, dan ada lima kasus studi, yaitu: 1). Kawasan perbukitan Candi Baru (1916). 2). Kawasan Pekunden, Peterongan, Batan, Wonodri (1919). 3). Kawasan Sompok (1919). 4). Kawasan Semarang Timur (1919). 5). Kawasan Mlaten (1924).

Kasus studi yang dibahas pada makalah ini adalah kawasan perbukitan Candi Baru, sebagai karya pertama Karsten di Kota Semarang (tahun 1916). Kasus dipilih karena kawasan Candi Baru adalah kawasan pertama yang direncanakan oleh Karsten. Kawasan ini memiliki ketinggian $90 \mathrm{~m}$ di atas permukaan laut, dan memiliki kontur tanah yang sangat curam. Permukiman ini sangat mencerminkan konsep lokal pada perencanaannya. Metode Operasional Penelitian

\section{Tahap 1}

Peta perencanaan perluasan Kota Semarang oleh Karsten (Gambar 5) dijadikan sebagai titik awal untuk mengamatai kasus studi. Hal ini untuk menentukan batas fisik kasus studi. Peta ini memperlihatkan lima kawasan kasus studi yang direncanakan oleh Karsten, dan fokus pembahasan pada kawasan Candi Baru.

Melalui pendekatan teori tissue kota, dapat diambil satu tissue kawasan, yaitu tissue kawasan Candi Baru (gambar 5). Dengan teori tissue kota juga dapat dibahas kawasan Raadsplein di Candi Baru (gambar 6).

Tahap 2

Pada kasus studi Kawasan Candi Baru diungkap konsep lokal yang memengaruhi Karsten.

\section{Tahap 3}

Tahap ini menginterpretasikan peran lokalitas pada perencanaan kota pada kawasan Candi Baru di Kota Semarang.

Metode Analisis Data

Data collection is from secondary and Metode analisis data yang dilakukan dalam penelitian ini adalah sebagai berikut:
1. Langkah awal yang dilaksanakan adalah mengumpulkan semua peta perencanaan Kota Semarang oleh Karsten.

2. Analisis terhadap peta-peta Kota Semarang menghasilkan peta morfologis terbentuknya kawasan Candi Baru

3. Selanjutnya dilakukan pengolahan data dengan melakukan komparasi antar literatur untuk menginterpretasi data empirik secara kualitatif. Setelah ini dapat dilakukan interpretasi elemen primer kota dan tissue kota yang terdapat pada kawasan Candi Baru

4. Analisis terhadap pola tatanan kawasan, bangunan penting pada kawasan Candi Baru, mendapatkan peran lokalitas pada karya Karsten

5. Penyimpulan konsep lokal didasarkan pada telaah teori Coté, telaah konsep kota Jawa, yang terkait dengan teori Ordering Principle, dan telaah teori people, place, dan period. Selanjutnya dilakukan pemetaan elemen primer kota yang dipengaruhi aspek lokal.

6. Penyimpulan dan rekomendasi mengenai konsep lokal pada karya Karsten.

\section{Hasil dan Diskusi}

\section{Penentuan Batas Area Kawasan Candi Baru}

Kota Semarang bagian bawah, mengalami masalah kesehatan kota di tahun 1910, yang harus diperbaiki. Kota Semarang bawah sebagai dataran rendah, saat itu tidak mungkin diperbaiki (Muljadinata, 1993: 49) [9]. Sebagai tindak lanjut, dilakukan eksploitasi daerah perbukitan atas Kota Semarang, yaitu bukit Candi Baru, yang merupakan lahan pemakaman Cina (Liem, 1931: 194) [10]; dan juga merupakan batas di sebelah selatan Kota Semarang.

Sebelumnya pada tahun 1910 dinas yang ada dalam gemeenteraad 
(pemerintah kota praja) Kota Semarang telah memiliki perencanaan seperti yang terlihat dalam peta berikut ini.

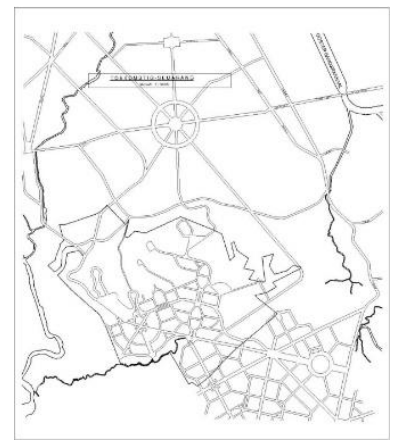

Gambar 1: Peta Awal Candi Baru, 1910 (Sumber: Toekomstig Semarang, 1914: 1,2, Redrawing)

Di awal tahap persiapan, pemerintah kotapraja saat itu membuat peta rencana perluasan Kota Semarang (Gambar 1) (Toekomstig Semarang, 1910: 1,2) [11].

Peta ini tidak digunakan sebagai rencana perluasan Kota Semarang. Kalau diteliti dengan cermat, peta ini untuk diterapkan pada lahan datar; padahal lahan Candi Baru memiliki kontur yang sangat curam dan terjal. Karsten merencanakan permukiman kawasan Candi Baru pada tahun 1906. Gambar 2 mrupakan peta yang dibuat oleh Karsten pada tahun 1906. Pada peta ini terlihat garis-garis kontur tanah yang mengindikasikan kontur tanah yang terjal pada lahan perbukitan Candi Baru.

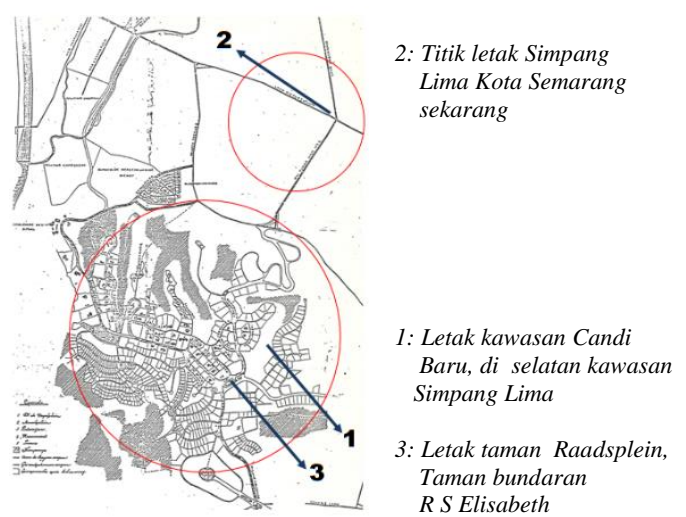

Gambar 2: Peta Perencanaan Candi Baru oleh Karsten (Sumber Bogaers, 1983) [12].

Pada gambar 2 terlihat taman raadsplein terletak pada no.3, dan embrio simpang lima pada no.2. Karsten juga merencanakan dengan rinci kawasan sekitar taman raadsplein (sekarang taman bundaran menuju RS Elisabeth), lihat gambar 3.

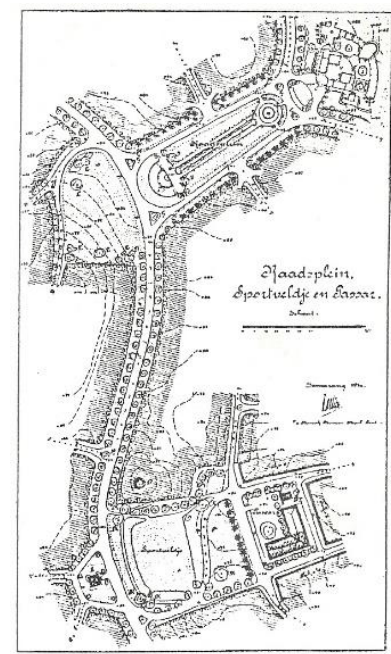

\section{Gambar 3: Peta Raadsplein} (Sumber: Plate) [13].

Berdasarkan analisis peta tahun 1909 (Gambar 4), morfologi Kota Semarang berkembang dengan jelas ke arah Selatan dan Barat Kota Semarang. Peta morfologis tahun 1909 ini memperlihatkan, jalan yang sudah ada adalah jalan Gajahmada, jalan Pandanaran dan jalan A.Yani, dan belum terlihat jalan K.H Ahmad Dahlan dan jalan Pahlawan. Peta ini memperlihatkan, perkembangan Kota Semarang menjauhi Kota Lama. Kawasan pengembangan kota jauh lebih luas dari pada luas kota kolonial Semarang ini. Pembangunan kota hanya terjadi pada jalan utama saja.

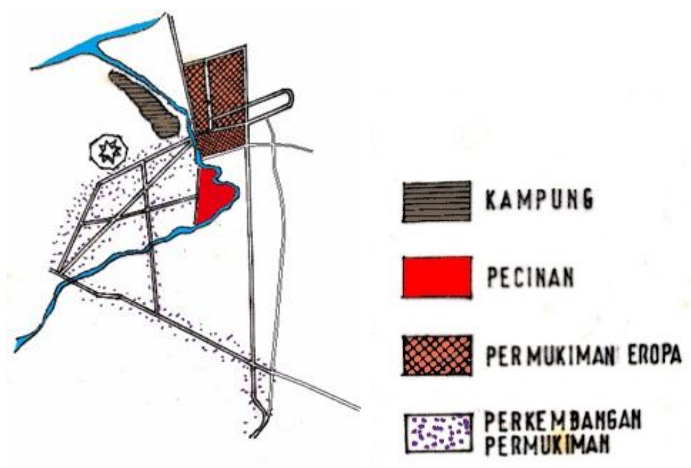

1909

Gambar 4: Peta Morfologis Kota Semarang 1909 - Redrawing. Penyempurnaan Gambar Peta dari Fordis 6 [14]. 
Dalam perkembangan selanjutnya setelah perencanaan kawasan Candi Baru, Karsten merencanakan perluasan Kota Semarang di luar kota lama, menjadi kota modern.

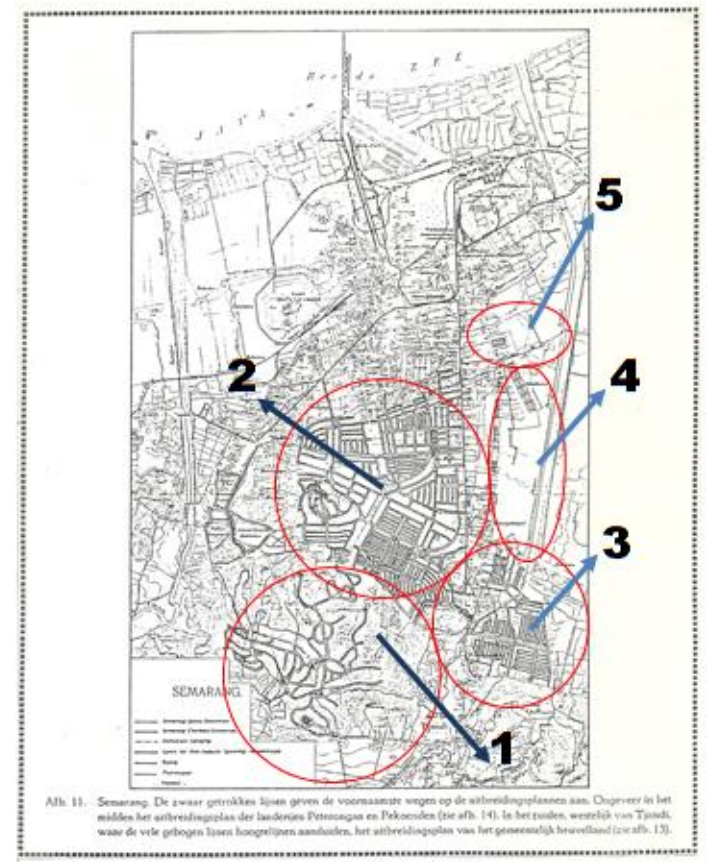

Gambar 5. Peta Perluasan Kota Semarang Tahun 1922 Oleh Karsten

Setelah Karsten merencanakan perluasan Kota Semarang pada bagian kawasan yang lain, peta perluasan Kota Semarang yang didesain Karsten pada tahun 1922 menjadi seperti yang terlihat pada gambar 5 . Dengan demikian disimpulkan, bahwa Kota Semarang sebagai Kota Modern, dirancang oleh Herman Thomas Karsten.

Pada peta yang direncanakan oleh Karsten pada tahun 1922, sudah terlihat jalan K.H. Ahmad Dahlan/jalan Seroja dan juga jalan Pahlawan (namun belum terbangun). Jalan Pahlawan dirancang Karsten untuk menghubungkan Kota Semarang bagian bawah dengan kawasan Candi Baru (Kota Semarang bagian tas). Dengan demikian dapatlah disimpulkan bahwa Karstenlah yang menciptakan embrio kawasan Simpang Lima di dalam Kota Semarang sebagai kota modern, merencanakan jalan Pahlawan dan jalan K.H. Ahmad Dahlan. Saat ini kawasan Simpang Lima merupakan kawasan pusat Kota Semarang yang sangat ramai.

\section{Konsep Lokal pada Perencanaan Kota}

Konsep lokal selalu terkait dengan people, place, dan period [15] People/manusia selalu terkait dengan budaya, peradaban, dan tradisi. Karya arsitektur selalu dipengaruhi oleh tradisi manusianya. Place/tempat merupakan wadah, yang menampung segala aktifitas. Tempat terkait dengan keadaan geografi, topografi, iklim, lingkungan alam semesta, dan lingkungan binaan. Time/waktu/tempo/era berkaitan dengan era saat suatu karya dihasilkan. Dengan demikian, konsep lokal menjadi faktor penentu suatu karya arsitektur dan kota.

Karsten berada pada era arsitektur modern dan garden city, yang merupakan hasil pemikiran tokoh-tokoh Eropa/Barat. $\mathrm{Hal}$ ini memengaruhi pemikiran Karsten yang juga mendalami pemikiran Jawa/lokal. Kolaborasi pemikiran barat dan pemikiran lokal, menghasilkan konsep lokal Karsten. Konsep lokal Karsten adalah:

- Signifikansi Basis Ekonomi

- Konteks Lingkungan

- Aspek Pemikiran Jawa [16].

Hal ini diwujudkan Karsten dalam merencanakan kawasan Candi Baru melalui pemikiran yang cermat terkait dengan elemen primer kota, dalam suatu town planning yang indah.

\section{Signifikansi Basis Ekonomi}

Area Candi Baru, sejak perencanaan awalnya, memang diperuntukkan bagi masyarakat yang memiliki strata ekonomi atas. Namun, Karsten juga merencanakan kompleks hunian untuk masyarakat ekonomi lemah. Hunian ini berbentuk perkampungan untuk rakyat miskin. Jadi dalam ini, ia menerapkan kampung kota. Pada Gambar 6 terlihat pengelompokan hunian yang didasarkan pada basis ekonomi. 


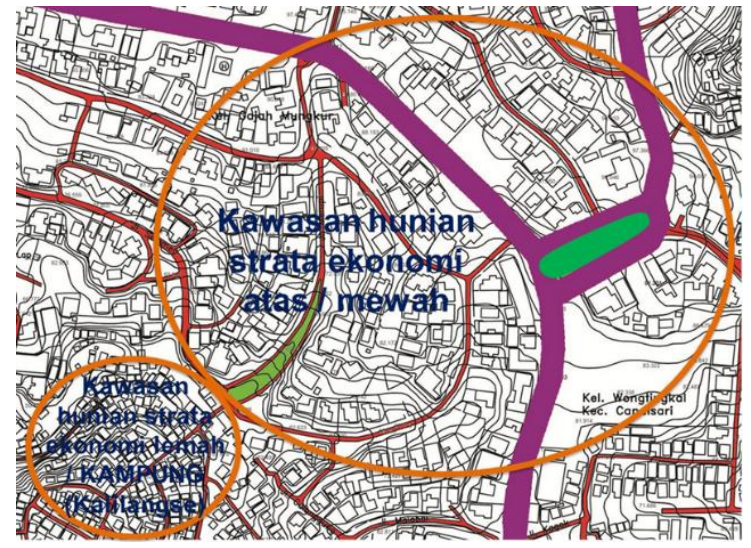

\section{Gambar 6: Pengelompokan Hunian Di Sekitar Raadsplein}

Gambar 7 memperlihatkan rumah tipe kampung yang dirancang oleh Karsten. Istilah Kampung tidak pernah ada pada teori kota pada era Arsitektur Modern. Kampung adalah lokalitas yang khusus ada di Indonesia. Gambar 8 memperlihatkan bentuk kampung dengan penataan huniannya. Pada Gambar 7 dan Gambar 8 terlihat pola tatanan kampung dengan huniannya yang bertipe bangunan tunggal beserta pekarangannya.

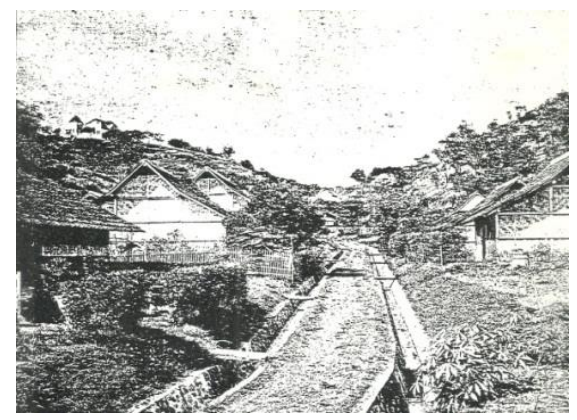

Gambar 7: Rumah Kampung di Awal Perencanaan Tahun 1906 Di Kalilangse

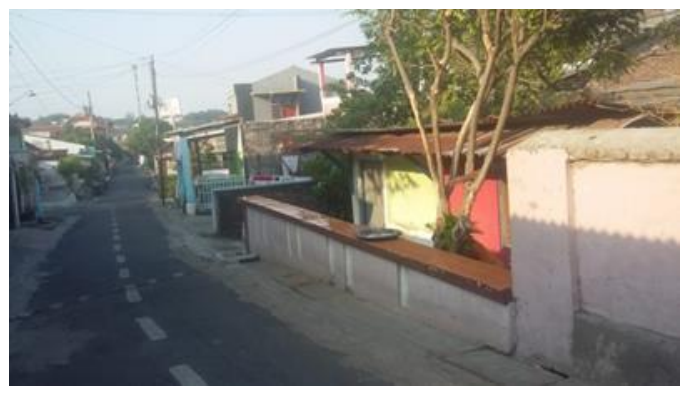

Gambar 8. Kalilangse Kampung Tahun 2020

Gambar 7 dan 8 memperlihatkan adanya pola kampung yang sangat kuat, dengan tipe bangunan tunggal dan pekarangan.

\section{Konteks Lingkungan}

Saat direncanakan menjadi kawasan permukiman, area Candibaru masih merupakan area perbukitan hijau tanpa hunian, dan digunakan sebagai lahan pemakaman masyarakat Tionghoa. Perencanaan kawasan Candibaru mengalami kendala permasalahan kontur yang curam. Curamnya kontur terlihat pada Gambar 6. Titik tertinggi pada area ini dipilih oleh Karsten sebagai awal perencanaannya. Titik tertinggi adalah Raadsplein/Taman Diponegoro. Taman ini memiliki ketinggian $90 \mathrm{~m}$ di atas permukaan laut.

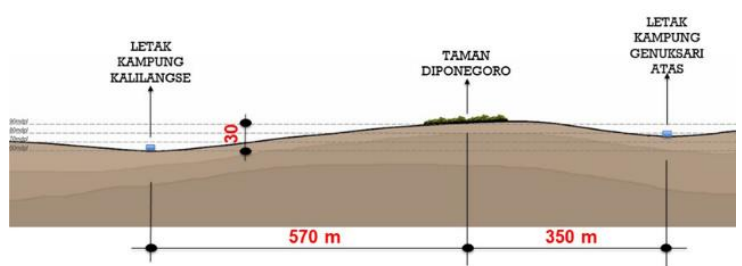

POTONGAN MELALUI SUMBU KAWASAN RAADSPLEIN

\section{Gambar 8. Candi Baru Land Contour Conditions}

Karsten merencanakan beberapa taman kota pada area perbukitan Candibaru, dan Raadsplein merupakan taman kota terbesar di kawasan ini. Semua bangunan di kawasan Candibaru merupakan tipe bangunan tuggal yang memiliki halaman yang luas. Jadi tipe free standing building dengan halaman ruang hijau yang luas menjadi ciri utama kawasan ini. Ini semua merupakan respon perencanaan kota terhadap kondisi lingkungan, juga terkait dengan iklim tropis.

\section{Aspek Pemikiran Jawa}

Sejak awal perencanaannya, zonasi kawasan menjadi bagian yang sangat penting. Dengan demikian, tatanan zonasi yang baik telah terencana dengan baik di kawasan ini.

Menurut Wiryomartono, dalam budaya masyarakat Jawa, terdapat Tradisi Zonasi. [17]. Zonasi ini memiliki pola radial concentrict. Pola ini mengacu pada pola kota Jawa di masa lalu. Pola ini memperlihatkan zonasi, yaitu 1. Pusat atau Negari yang dilengkapi dengan alun-alun, dan Masjid. 2. Kawasan Hunian para 
Hulubalang. 3. Kawasan Hunian Rakyat. Karsten sangat dipengaruhi tradisi zonasi Jawa dalam merencanakan zonasi kawasan ini. Gambar 9 memperlihatkan pola ini.

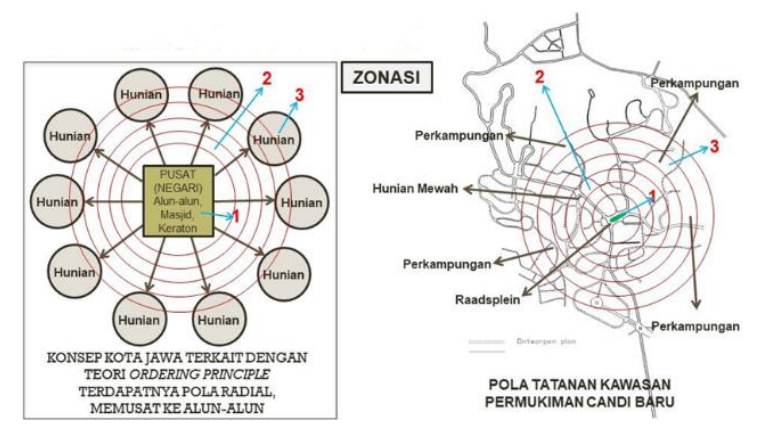

\section{Gambar 9. Analisis Pengaturan Kawasan Candi Baru}

Penataan kawasan Candibaru menerapkan analogi tradisi zonasi Jawa. Tempat yang tertinggi di kawasan ini dipilih sebagai pusat orientasi di kawasan Candibaru. Titik locus tertinggi dirancang sebagai sebuah taman kota yang luas, yaitu Raadsplein atau sekarang bernama Taman Diponegoro, taman di bundaran menuju RS. Elisabeth.

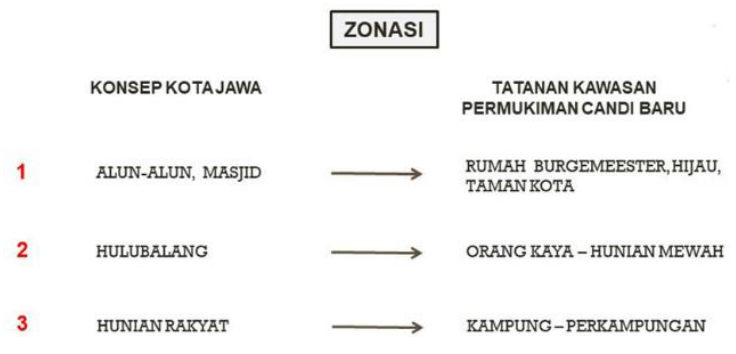

\section{Gambar 10. Analisis Zoning Kawasan Candi Baru}

Taman Diponegoro merupakan pusat orientasi yang didesain Karsten. Dari Taman ini sebagai pusat, diciptakan pola radial memusat. Raadsplein dianalogikan sebagai alun-alun kota/kawasan. Sumbu taman ini berakhir pada gedung Puri Wedari sebagai bangunan penting, yang digunakan sebagai rumah Pangdam. Puri Wedari merupakan rumah burgemeester / walikota pada masa itu.

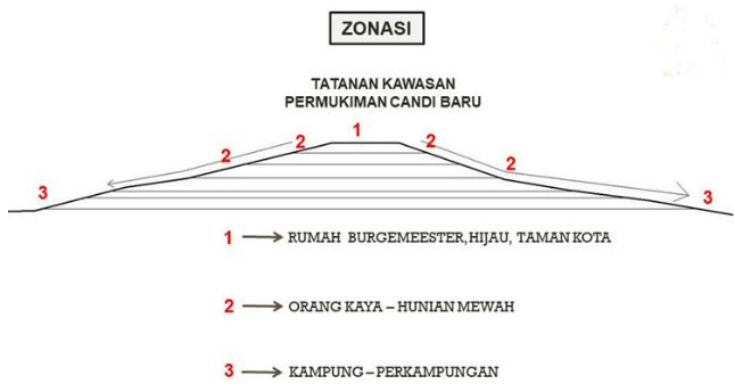

\section{Gambar 11. Analysis Potongan Kontur Candi Baru}

Rumah Pangdam ini diibaratkan sebagai keraton. Di sekitar Taman Diponegoro terdapat bangunan hunian mewah. Bangunan-bangunan rumah mewah merupakan analogi hunian hulu balang raja. Pada kawasan Candibaru yang paling rendah (di kontur lahan terendah) terdapat perkampungan, dan ini adalah analogi hunian rakyat. Hal ini dapat dilihat pada Gambar 10, Gambar 11, dan Gambar 12.

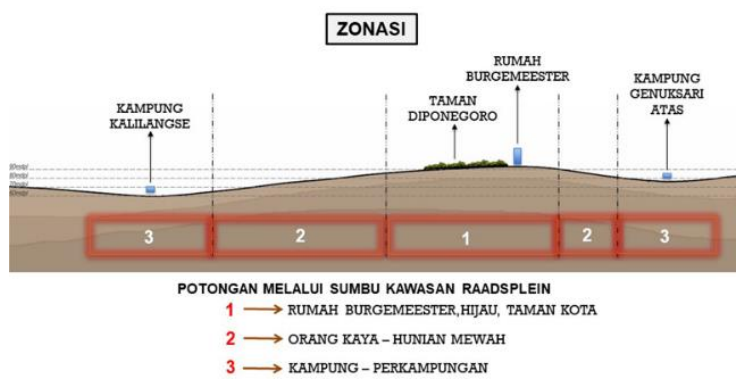

\section{Gambar 12. Analisis Analogi Zonasi Candi Baru}

\section{Kesimpulan}

Lokalitas selalu berkaitan dengan Signifikansi Basis Ekonomi, Konteks Lingkungan, dan Aspek Pemikiran Jawa, dapat dijumpai dengan jelas pada area Candi Baru. Secara keseluruhan, ke tiga aspek dalam konsep lokal dalam perencanaan kota ini, merupakan satu kontribusi bagi teori kota yang perwujudannya bisa dilihat pada elemen primer kota.

Penelitian ini menyimpulkan bahwa terdapat dominasi aspek lokal pada karya Karsten, dan adanya relasi yang sangat erat antara konsep lokal dan elemen primer kota. 
Penelitian ini memberi wawasan baru kepada para dosen dan mahasiswa arsitektur, bahwa aspek lokal yang selalu terkait dengan aspek budaya, sosial dan ekonomi, sangat penting dalam perancangan arsitektur saat ini. Pemahaman aspek lokal dan filosofi arsitektur tradisional merupakan bekal yang sangat penting bagi seorang arsitek. Bila hal ini menjadi basis dalam merancang karya arsitektur, dan dikembangkan dengan metode modern dalam merancang arsitektur, maka akan diperoleh karya arsitektur yang sangat inovatif.

Seorang arsitek harus memiliki pengetahuan dan pemahaman aspek lokal, sehingga dapat menghasilkan karya arsitektur yang sangat inovatif. Karya arsitektur yang diwarnai oleh aspek lokal, ternyata mampu bertahan di tengah kemajuan dan perkembangan jaman. Hal ini menjadi tantangan bagi pendidikan arsitektur di Indonesia saat ini!

\section{Daftar Pustaka}

[1] Akihary, Huib, "Architectuur en stedebouw in Indonesië 1870-1970', (1988), opdrachtgever: Rijksdienst voor de Monumentenorg Zeist, produktie: Grafiplan, Geeuwenbrug, September 1988, ISBN 72691024

[2] Coté, Joost \& Hugh O'Neill, (2017), "The Life and Work of Thomas Karsten", Architectura \& Natura, Amsterdam

[3] Muljadinata, A.S, 1994, "Penataan Kota Semarang Masa Lalu Dan Perkembangannya", Suatu telaah terhadap karya Karsten di Semarang, Makalah ini disajikan di dalam acara SDAP Seri XVI, di FT. Arsitektur Universitas Katolik Soegijapranata, Semarang, 9 April 1994.

[4] Nas, Peter J.M, (1986), "The Indonesian City", Studies in Urban Development and Planning, Foris Publications, Dordrect Holland/Cinnaminson-USA
[5] Muljadinata, A.S., 2016, "Karsten's Work in Architectural Conservation of Semarang", 3rd International Conference on Indonesian Architecture and Planning (ICIAP) "Inclusive Space, Enriching Culture", 3rd Biennale of ICIAP, August 11-12th, 2016, Yogyakarta, Department of Architecture and Planning, Universitas Gajah Mada, Yogyakarta.

[6] Djono, Tri Prasetyo Utomo, Slamet Subiyantoro, 2012. "Nilai Kearifan Lokal Rumah Tradisional Jawa, Humaniora", Vol.24, No.3, Oktober 2012

[7] Muljadinata, A.S dan Antonius Ardianto, (2004), "Regionalisme Pada Bangunan Arsitektur Karya Thomas Karsten Di Semarang", Semarang Oktober 2004

[8] Muljadinata, A.S, 2018, "The Role of Localities in Karsten's Works in Architecture and City of Semarang", IOP Conference Series: Earth and Envirionmental Science 126 (2018) 012007, IOP Publishing,doi: 10.1088/1755-1315/126//1/012007

[9] Muljadinata, A.S, (1993)."Karsten dan Penataan Kota Semarang", Tesis, ITB

[10] Thian Joe, Liem, (1931), "Riwajat Semarang", Dari Djamannja SAM POO Sampe Terhapoesnja KONGKOAN, Boekhandel Ho Kim Yoe, Semarang-Batavia, Tjitakan Pertama.

[11] Toekomstig Semarang (1910), Toelichting tot het voorontwerp uitbreidingsplan in het heuvelland. Uitgegeven door den Dienst van het gemeentelijk Grondbedrijf

[12] Bogaers, Erica, (1983), "Ir. Thomas Karsten En De Ontwikkeling Van De Stedebouw Nederlands-Indie 1915 - 1940', Amsterdam, Juni, 1983

[13] A. Plate, 1921/1922, "Het Uitbreidings Plan Der Indische Gemeenten", NION, Zesde Jaargang. 
[14] Muljadinata, A.S., 2018, “Dominasi dan Peran Aspek Lokal Pada Karya Herman Thomas Karsten", Prosiding Fordis 6, Forum Diskusi Metode Penelitian Arsitektur di Universitas Atmajaya Yogyakarta pada 13-14 September 2018

[15] Muljadinata, A.S, 2019, "Dominasi Penerapan Tradisi Jawa Pada Pola Tatanan Kota Karya Karsten", Prosiding Fordis 7, Forum Diskusi Metode Penelitian Arsitektur di Universitas Atmajaya Yogyakarta pada 23 Oktober 2019

[16] Muljadinata, A.S., 2021, "Penerapan Konsep Lokal Pada Perencanaan Kota Karya Karsten", Disertasi, Universitas Katolik Parahyangan, Bandung

[17] Wiryomartono, A. Bagoes, (1995), "Seni Bangunan dan Seni Bina Kota di Indonesia", Kajian mengenai Konsep, Struktur, dan Elemen Fisik Kota sejak peradaban Hindu-Budha, Islam hingga sekarang. Jakarta, PT Gramedia Pustaka Utama. 